\title{
SETTLEMENT COMPACTNESS AS A QUALITY CHARACTERISTIC OF LAND USE
}

\author{
Vladyslav SMILKA \\ Kyiv National University of Construction and Architecture, Kyiv, Ukraine \\ Corresponding author's e-mail:vlsmilka@gmail.com
}

\begin{abstract}
The aim of the research is to propose the method for forming an indicator of compactness of a populated population and to test it. The comparative analysis, structuring, geospatial modelling methods have been used in the research. Land use management and development regulation, which is carried out by urban planning documentation, is the spatial frame for sustainable territory development. Forming of quantitative and qualitative indicator system that characterises the level of urban development of a settlement is an overriding issue for state estimation of settlement development. Management decisions on land use management should be made taking into account the evaluation results. The compact form is an essential basis for the efficient and stable use of the settlement territorial resources. There is no single evaluation technique of settlement compactness; there are a variety of approaches and methods for the assessment of settlement form. The compactness level in this study is estimated by a system of indicators that attests to the multiplicity of land uses and the degree of accessibility to basic services and leisure facilities. The determining technique of component compactness has been tested in evaluating the planning structure of Kyiv. All planning quarters are rated according to a five-level rating scale. For each classification group, general recommendations have been developed to improve the land use system aimed at improving the compactness of the settlement. The results of compactness assessment can be used through geoinformation monitoring tools in the provision of administrative services as justification for managerial decision-making.
\end{abstract}

Keywords: compactness, evaluation, geoinformation monitoring, method, planning structure, settlement, sustainable development.

\section{INTRODUCTION}

The Global Sustainable Development Goals 2015-2030 are aimed at addressing over the last 15 years the major human problems of social equality, ensuring minimum living comforts and adapting humanity to climate threats (UNDP in Ukraine, 2015). Settlements are characterised by a high concentration of population per unit area, so the implementation of sustainable development principles for managing settlement territories is a significant step towards achieving global goals. The spatial frame for sustainable development of the territory is land use management and regulation of development, which are carried out by urban planning documentation (Kovalska \& Smilka, 2019). Information support for the management decision-making system is organised by cadastral and monitoring data. Cadastral systems provide information about the actual state of the 
environment, and monitoring systems provide the results of evaluating and forecasting the development of environmental objects, so the results of monitoring are determinative for management decisions. An important problem for assessing the state of development of a settlement is the formation of a system of quantitative and qualitative indicators that characterise the level of urban development of the settlement. Management decisions on land use management should be made based on the evaluation results.

The aim of the research is to propose a method for forming an indicator of compactness of a populated population and to test it.

\section{METHODS AND PROCEDURES}

The aim of the research is to propose a method for forming an indicator of compactness of a populated population and to test it. The comparative analysis, structuring, geospatial modelling methods have used in the research.

At the conference "Leipzig Charter on Sustainable European Cities", held in Leipzig on 24-25 May 2007, experts on urban development and territorial unity of European countries identified that "an important basis for efficient and sustainable use of resources is a compact settlement structure". Mathematicians George Bernard Dantzig and Thomas Lorie Saaty, who were driven by a desire to use territorial resources effectively, introduced the concept of a "compact city" in 1973. The concept of compactness in terms of site planning is associated with Jane Jacobs and her book "The Death and Life of Great American Cities" (Jacobs, 1961; Bochkarov, 2019).

Compact structures of settlements are characterised by the following features (Bochkarov, 2019):

1. Built-up density. David Locke identified the need to maximize the use of already built-up territory before exploring free space (Yu \& Zhou, 2011); Effective use of the territory is ensured to prevent the chaotic expansion of settlements and, as a consequence, to promote the dependence of residents on road transport (Jenks, Burton, \& Williams (eds)., 1996);

2. Mixed-use of territories (multi-purpose design). Providing a combination of various activities (housing, work, shopping, and leisure) in a restricted space within walking distance or with minimal use of public transport (OECD, 2012; Le Corbusier, 2011);

3. Priority for public transport and restrictions on the use of private cars. The use of public transport instead of private cars is an important component of a compact city as an environmental aspect. Public transport conveys groups of people, as opposed to individual vehicles, which affects traffic congestion. Besides, in the settlements, large areas are occupied by infrastructure for individual vehicles, namely, parking spaces, gas stations. The development of public transport contributes to the environmental friendliness of settlements by reducing harmful emissions into the atmosphere and saving territorial resources (Geurs \& Bert, 2006). 
These features provide an opportunity to assess the quality of land use of settlements in the following aspects: a) accessibility to service and recreation facilities; b) the level of multifunctional use of land plots (Fig. 1). There is no single method for assessing the compactness of a settlement; there are different approaches and methods for assessing settlement form. Researchers determine many indicators that characterise the shape of settlements, in particular: density (size of the territory), indicators of land use diversity (distribution of territory), indicators of transport support (human function), architectural and planning indicators (Jenks \& Burgess (eds.), 2004; Kotharkar, Bahadure \& Sarda, 2014; Williams, Burton \& Jenks, 2000; Bass Warner, 2011; Whitehead, 2000).
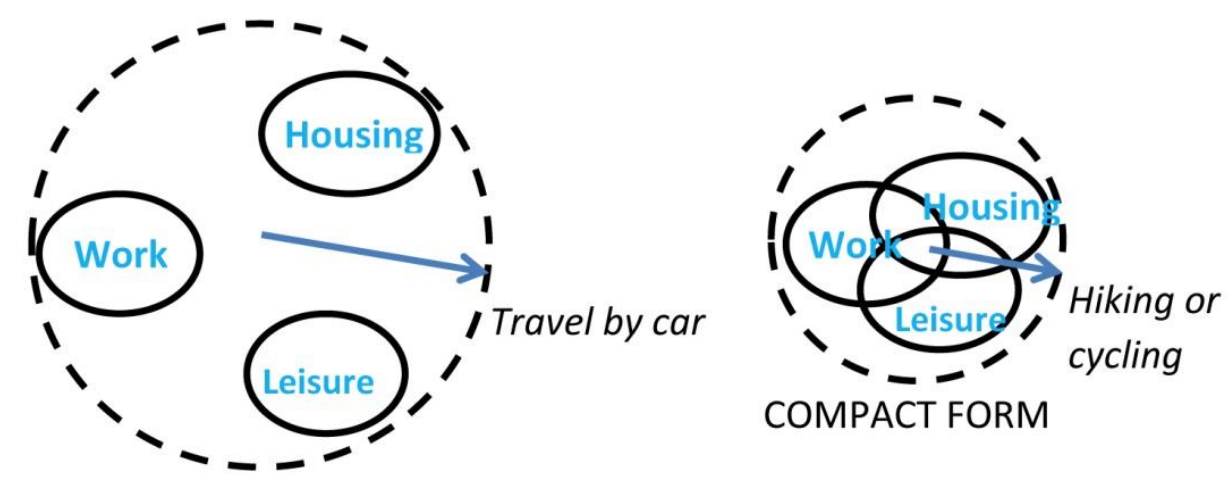

Fig. 1. Visualisation of the content of settlement compactness (Rogers, R. 1997, p. 39).

The choice of indicators for assessing settlement compactness or its planning structures is conditioned by the complexity and sufficiency of data to calculate the relevant indicators using analytical tools of geoinformation monitoring. As an example of compactness estimation, it is proposed to use the research of Spanish scientists (AEU de Barcelona, 2008; AEU de Barcelona, 2011; LLA CTA lab Guidades Sustentables, 2015; Rueda, 2002). The compactness index of settlements consists of two indicators and is a characteristic of sustainable development in terms of density and accessibility (Table 1).

Table 1. The Index Structure of Compactness of Land of Settlements (developed by the author, based on (Cabrera-Jara, Orellana \& Hermida, 2017))

\begin{tabular}{|c|c|c|}
\hline Indicator & Rate & Standard, desirable value \\
\hline Multiple land uses & $\begin{array}{l}\text { Population density } \\
\text { Complexity of land use } \\
\text { Area per capita }\end{array}$ & $\begin{array}{c}\leq 450(540) \text { persons/ha } \\
>2 \\
6-15 \mathrm{Sqm} / \text { person }\end{array}$ \\
\hline Accessibility & $\begin{array}{l}\text { Aggregate proximity to public facilities } \\
\text { Aggregate proximity to public } \\
\text { transportation } \\
\text { Aggregate proximity to green areas }\end{array}$ & $\begin{array}{l}100 \% \\
100 \% \\
100 \% \\
\end{array}$ \\
\hline
\end{tabular}


The indicator "multiple land uses" is formed from indicators "population density", "complexity of land use" and "area per capita". The indicator "accessibility" is formed from indicators "aggregate proximity to public facilities", "aggregate proximity to public transportation", and "aggregate proximity to green areas".

\section{DATA INTERPRETATION}

The compactness level of Kyiv urban planning structures was investigated. The data for the calculation were obtained from the land and city planning cadastre systems, which are updated by the Department of Land Resources and the Department of Urban Planning and Architecture of the executive body of Kyiv City Council (Kyiv City State Administration). The results of the evaluation of land use diversity and accessibility were reflected in the development of recommendations for improving the land use structure of Kyiv.

\subsection{Multiple Types of Land Use}

The indicator of multiple land uses consists of population density indicators, complexity of land use, area per capita (AEU de Barcelona, 2008; AEU de Barcelona, 2011; LLA CTA lab Guidades Sustentables, 2015).

The density of any values is a feature of spatial capacity and is widely used to estimate dissemination. The density can characterise space differently; depending on the purpose of estimation, different values are used, in particular absolute and average values of the territory (Kotharkar, Bahadure \& Sarda, 2014). The evaluation process is done by comparing normative values with actual ones. The average values of the territory density are used for further research since state building standards regulate the population density of the planning quarter of the settlement. Population density is determined by the ratio of the population within the planning district to the neighbourhood area. The complexity level of land use demonstrates the completeness of meeting the needs of residents (within the territory of the planning quarter) on the principle of "walking distance" and is a sign of the compactness of the architectural and planning element of the settlement. The content of a land use complexity indicator is to present information about the organisation of a settlement system as a numerical message describing many uses of land and services within a unit of space. The Land Use Complexity Index highlights several aspects of land use and indicates:

- diversity and combination of human needs and functions;

- the degree of socio-economic capital of settlements;

- the level of competitiveness and attractiveness of settlements (AEU de Barcelona, 2008; AEU de Barcelona, 2011; LLA CTA lab Guidades Sustentables, 2015).

Land use complexity is determined by the Shannon formula (Eq. 1):

$$
W=-\sum_{i=1}^{m} \frac{a_{i}}{a} \log _{2} \frac{a_{i}}{a},
$$


where

$W$ - the scope of information contained in the message;

$a_{i}$ - the number of different land uses that occur within the selected space;

$a$ - the total number of plots within the selected space.

Public, lifestyle and industrial facilities are classified into typological groups based on satisfaction of public, social, cultural, household and consumer needs of the person. The satisfaction of human needs within a unit of space determines the level of land use complexity. The classification of land use is generalised in the study. The indicator of land use complexity is typical of all functional zones of the settlement - housing, public, industrial and recreational.

The landscape and shade gardening level of the territory is one of the indicators of human life support (AEU de Barcelona, 2008; AEU de Barcelona, 2011; LLA CTA lab Guidades Sustentables, 2015). The indicator highlights the actual availability of planning structures in open and green areas. This indicator is regulated by state building codes and is defined as the ratio of greened areas to the population within the planning quarter.

The indicators highlight the social, environmental and economic aspects of settlements.

\subsection{Accessibility of Services and Recreation Places}

The indicator of accessibility to services and recreation places consists of a group of aggregate proximity indicators to public services, to stops of three modes of transport and green zones of three types (AEU de Barcelona, 2008; AEU de Barcelona, 2011; LLA CTA lab Guidades Sustentables, 2015).

State building codes set service radii for day-to-day and periodic service establishments. These include scholastic institutions, food and non-food stores, medical facilities and pharmacies, gyms, cultural and household purpose institutions.

The formula for calculating the proximity index to public service institutions is as follows (see Eq. 2):

$$
D U_{i}=\frac{1}{12} \times \sum_{j=1}^{n}\left(\frac{h_{i}^{j}}{H_{i}}\right) \times 100,
$$

where

$D U_{i}$ - an indicator of proximity to the $i$-th element of the planning structure;

$H_{i}$ - total area of the $i$-th element of the planning structure;

$h_{i}^{j} \quad$ - the area of the $i$-th element of the planning structure located within the service area of the $j$-th public service object;

$n$ - the number of types of public service institutions.

The population should be provided with alternative modes of public transport. A person must have a choice in the use of transport - subway, high-speed tram, tram, trolleybus, or bus.

The formula for calculating the proximity to stops of three modes of public transport is as follows (Eq. 3): 


$$
D T_{i}=\frac{\left(h_{i}\right)_{3}}{H_{i}} \times 100
$$

where

$D T_{i}$ - an indicator of proximity to public transport stops;

$H_{i} \quad$ - total area of the $i$-th element of the planning structure;

$\left(h_{i}\right)_{3}$ - the area of the $i$-th element of the planning structure located within a distance of three types of public transport stops.

The proximity of green areas of public use for daily and weekly rest of the population is regulated by law and is:

- for squares at the micro-district level with the pedestrian movement of up to $10 \mathrm{~min}$;

- for small parks at the district level with the pedestrian movement of up to $15 \mathrm{~min}$;

- for large city parks with public transport up to $20 \mathrm{~min}$.

The index of simultaneous proximity to the three types of green areas is determined by the following detailed formula (Eq. 4):

$$
D Z_{i}=\frac{\sqrt[3]{h_{i}^{\mathrm{B} 1} \times h_{i}^{\mathrm{B} 2} \times h_{i}^{\mathrm{B} 3}}}{H_{i}} \times 100
$$

where

$D Z_{i}$ - an indicator of simultaneous proximity to the three types of green areas of the planning structure element;

$H_{i} \quad$ - total area of the $i$-th element of the planning structure;

$h_{i}^{\mathrm{B} 1}, h_{i}^{\mathrm{B} 2}, h_{i}^{\mathrm{B} 3}$ - parts of the area of the $i$-th element of the planning structure, classified according to the classification signs to the green zones of the microdistrict, district and city levels, respectively.

\section{RESULTS AND DISCUSSION}

The calculation results of the components of the compactness index are normalized to a range of values from " 0 " to " 1 " to bring the values to a single unit of assessment. The most appropriate value is " 1 " and the worst condition is " 0 " (LLA CTA lab Guidades Sustentables., 2015).

The calculation methodology can be automated in the environment of geoinformation systems since the inventories are kept in the form of geospatial data and the monitoring results must be provided in a spatial dimension (Lyashchenko \& Patrakayev, 2015).

Normalized values of population density, land use complexity, landscaping level, accessibility to public service institutions, public transport stops, and green areas of planning quarters of Kyiv are given in Table 2.

Indicator generalization for major planning entities, in particular districts, zones and cities as a whole, is made using the formula of the weighted average of its constituent elements. The compactness ratio scheme, which is under study now, concerns residential areas, so further development of recommendations for 
improving the effectiveness of social, environmental and economic land use conditions will apply to residential areas identified in urban planning documents (Lyashchenko \& Patrakayev, 2015).

Table 2. Components of Kyiv Compactness Index (developed by the author)

\begin{tabular}{|c|c|c|c|}
\hline \multicolumn{2}{|c|}{$\begin{array}{l}\text { Composite indicators of multiple types of } \\
\text { land use }\end{array}$} & \multicolumn{2}{|c|}{ Component indicators of the accessibility } \\
\hline Name & Spatial dimension index & Name & Spatial dimension index \\
\hline 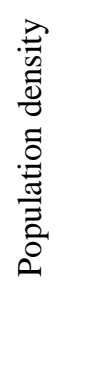 & 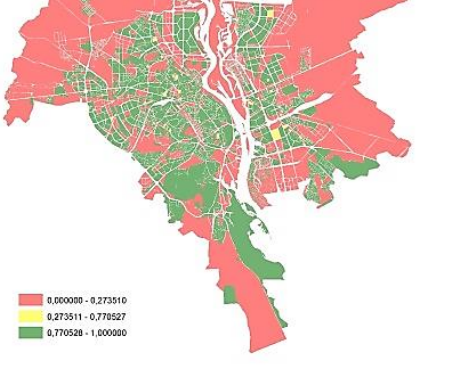 & 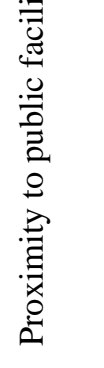 & 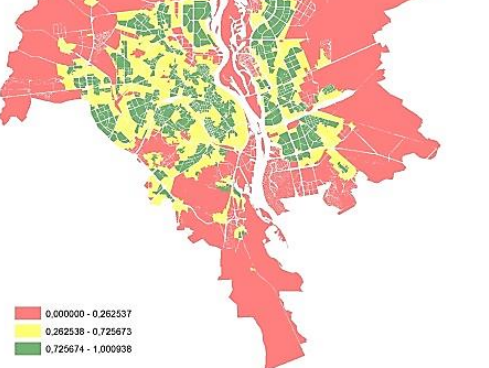 \\
\hline 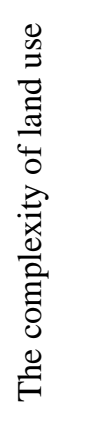 & E. & 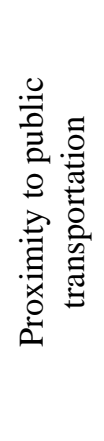 & 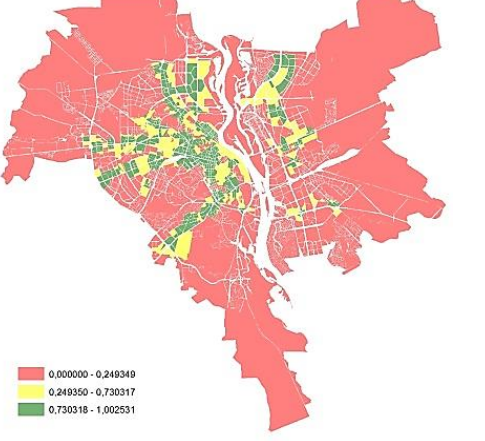 \\
\hline 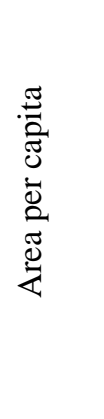 & 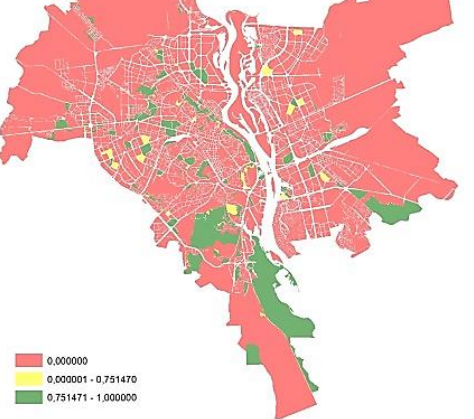 & 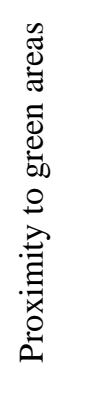 & 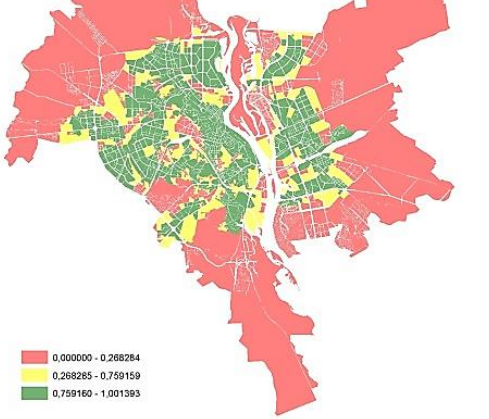 \\
\hline
\end{tabular}

Improving the indicator level lies in the area of responsibility of local governments and businesses (investors).

The generalised values for calculating the compactness level of residential districts of Kyiv are shown in Fig. 2. 


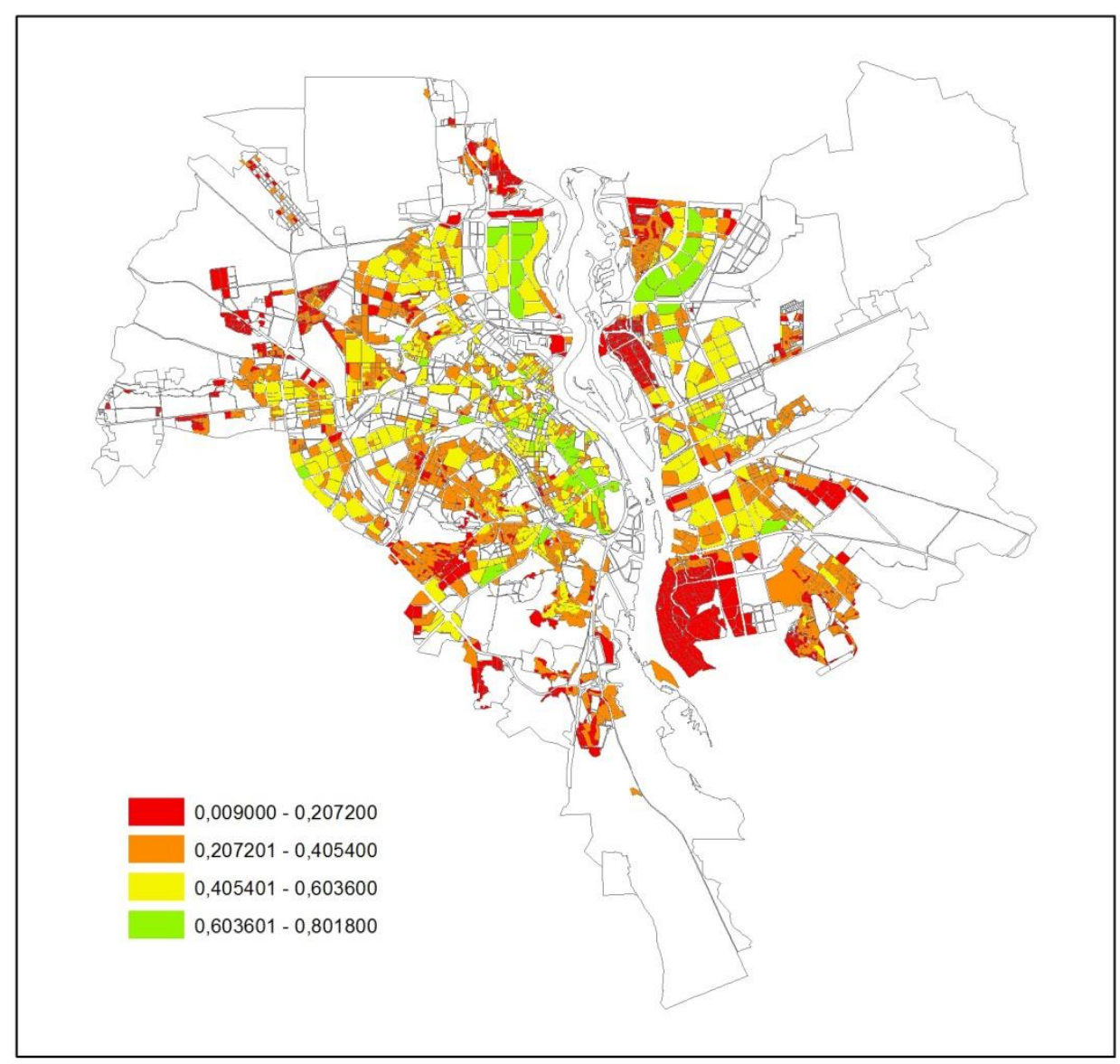

Fig. 2. Generalised compactness index of residential districts of Kyiv (developed by the author).

Further recommendations for land use should be developed for the quarters according to an evaluation scale that characterises the quality of land use:

- from 0.0 to 0.2 - low compactness level;

- from 0.2 to 0.4 - reduced compactness level;

- from 0.4 to 0.6 - average compactness level;

- from 0.6 to 0.8 - sufficient compactness level;

- from 0.8 to 1.0 - optimum compactness level.

According to the results of the calculation, it is determined that the maximum level of compactness index for Kyiv is 0.755 , which corresponds to a sufficient compactness level. It should be noted there are no planning quarters in Kyiv, which are assigned to the optimum compactness level. The weighted average compactness level for the entire city is 0.251 , which characterises the city as not compact enough.

Recommendations for improving land use should be made separately for each planning quarter. However, it is possible to distinguish general recommendations of the quarter groups assigned to each compactness assessment level. The recommendations are divided into two classes: those regulated by local governments and those regulated by the business (investors) (Chernyaga, 
Melnichuk \& Nimkovich, 2007; Petrakovska, 2007; Shubovych, Solovieva \& Panova, 2009).

For low-density compactness, the author of the paper recommends:

- for local self-government bodies - to take measures on development of town planning documentation, in the framework of which to solve problems of transport provision of the territory by different types of transport, regulation of urban planning activity and designing of public centres with full complexes of public services, entertainment of the population;

- for business - to initiate the development of town planning documentation, to change the type of land use from residential development to the public in the established order, with the further organisation of trade and entertainment establishments.

For reduced compactness, the author of the paper recommends:

- for local self-government bodies - to take measures for the development of town planning documentation, as part of which to solve problems of securing the territory by educational and medical institutions, as well as planning the territory for the creation of green areas of public use;

- for business - to change the type of land use from residential development to public in the established order, with the further organisation of trade and entertaining, physical and health improving establishments.

For average compactness, the author of the paper recommends:

- for local self-government bodies - to take measures for the development of town planning documentation, which includes the planning of the territory for the creation of cultural, physical and health-improving institutions, green public areas and development of recreational zones for population leisure area;

- for business - in the established order to take measures to transfer premises from the housing stock to non-residential with the subsequent organisation of trade, entertaining, sports institutions, conducting specialised competitive studies to choose the most optimal places of the arrangement of public service establishments.

For sufficient compactness, it is recommended:

- for local governments - to regulate the use of land by the purpose of land plots, to take measures to detect violations of land and urban planning legislation, considering public interests in urban planning of the settlement;

- business - to improve the efficiency of use of the territory, conducting specialised competitive research to select the most optimal places of the arrangement of public service establishments.

For neighbourhoods classified as optimal compactness, local governments are advised to regulate urban development and economic activity to maintain compactness. Construction, reconstruction of the objects of construction must be carried out without significant deviations to prevent the change of land use.

The evaluation results can be taken into account in urban planning, consideration of allotment issues, land ownership, and use (Tretiak, et al., 2017). The optimality of the solution can be determined provided that the design state of 
land use type or the selected type of construction object will help increase the level of compactness of the planning quarter and the city as a whole.

\section{CONCLUSION}

The article establishes that an important basis for the effective and stable use of a settlement's territorial resources is its compact form. The methodology for determining the compactness index of settlements, which has been tested when assessing the planning structure of Kyiv, has been proposed in the paper. The compactness index of settlements consists of two indicators and is a characteristic of sustainable development in terms of density and accessibility. The calculation of the indicators of settlement compactness or its planning structures has been carried out with the help of analytical tools of geoinformation monitoring.

As a result of testing the methodology, it has been found that the weighted average level of compactness for Kyiv characterizes the city as not compact enough. Recommendations are given for neighbourhoods that are classified as low, reduced, average, sufficient levels of compactness, which will contribute to the gradual establishment of optimum compactness of the city as a whole. The results of compactness assessment can be used in the administrative decision-making process in the provision of administrative services as the substantive information on which the decisions are made.

\section{REFERENCES}

AEU de Barcelona. (2008). Plan Especial de Indicadores de ostenibilidad Ambiental de la Actividad Urbanística de Sevilla. Gerencia de Urbanismo. Ayuntamiento de Sevilla. Agencia de Ecologia Urbana de Barcelona, $123 \mathrm{p}$.

AEU de Barcelona. (2011). Indicadores. Sistema de indicadores y condicionantes para ciudades grandes y medianas. Agencia de Ecologia Urbana de Barcelona, $82 \mathrm{p}$.

Bass Warner, S. (2011). The City Reader. Evolution and Transformation: The American Industrial Metropolis, 1840-1940, 55-64.

Bochkarov, S. (2019). The compact city: the Dutch experience. Retrieved from https://mistosite.org.ua/ru/articles/kompaktne-misto-niderlandskyi-dosvid

Cabrera-Jara, N., Orellana, D., \& Hermida, M. A. (2017). Assessing sustainable urban densification using geographic information systems. International Journal of Sustainable Building Technology and Urban Development, 8(2), 237-243. https://doi.org/10.12972/susb.20170021

Chernyaga, P., Melnichuk, O., \& Nimkovich, R. (2007). Land management as a means of balanced development of the territory. Modern achievements of geodetic science and production, 13(1), 244-247.

Geurs, K. T., \& Van Wee, B. (2006). Ex-post Evaluation of Thirty Years of Compact Urban Development in the Netherlands. Urban Studies, 43(1), 139-160. https://doi.org/10.1080/00420980500409318

Jacobs, J. (1961). The Death and Life of Great American Cities. New York: Vintage Books, 345 p.

Jenks, M., \& Burgess, R. (eds). (2004). Compact Cities: Sustainable Urban Forms for Developing Countries. Taylor \& Francis e-Library, $356 \mathrm{p}$.

Jenks, M., Burton, E., \& Williams, K. (eds). (1996). The Compact City: A Sustainable Urban Form? E \& FN Spon, London.

Kotharkar, R., Bahadure, P., \& Sarda, N. (2014). Measuring Compact Urban Form: A Case of Nagpur City, India. Sustainability, 6(7) 4246-4272. https://doi.org/10.3390/su6074246 
Kovalska, G., \& Smilka, V. (2019). Construction management in Ukraine. International Journal of Innovative Technology and Exploring Engineering (IJITEE), 9(1), 1593-1600. http://doi.org/10.35940/ijitee.A4563.119119

Le Corbusier. (2011). The City Reader. A Contemporary City, pp. 336-344.

LLA CTA lab Guidades Sustentables. (2015). La ciudad es esto. Medicion y representacion espacial para ciudades compactas y sustentables. Universidad de Cuenca. LLA CTA lab Guidades Sustentables, $156 \mathrm{p}$.

Lyashchenko, A., \& Patrakayev, I. (2015). Ontology and features of components of geoinformation monitoring by technology of geospatial data bases. Modern Achievements of Geodetic Science and Production, 1, 174-177.

OECD. (2012). Compact City Policies: A Comparative Assessment. OECD Green Growth Studies, $284 \mathrm{p}$.

Petrakovska, O. (2007). Methodology of management of the land use system of major cities. Extended abstract of Doctor's thesis Kyiv.

Rogers, R. (1997). Cities for a small planet. Basic Books, $179 \mathrm{p}$.

Rueda, S. (2002). Barcelona, ciutat mediterrània, compacta i complexa. Una visió de futur més sostenible, Ed. Ayuntamiento de Barcelona.

Shubovych, S., Solovieva O., \& Panova L. (2009). Introduction to architectural monitoring of the urban environment, $204 \mathrm{p}$.

Tretiak, A., et al. (2017). Land Use Ecology. Institute of Environmental Management and Balanced Nature Management, $178 \mathrm{p}$.

UNDP in Ukraine. (2015). Global Sustainable Development Goals 2015-2030, Retrieved from: https://www.ua.undp.org/content/ukraine/uk/home/sustainable-development-goals.html

Whitehead, T. (2000). The Formation of the U.S. Racialized Urban Ghetto. The Cultural Systems Analysis Group, 1-23.

Williams, K., Burton, E., \& Jenks, M. (2000). Achieving Sustainable Urban Form, 202 p. https://doi.org/10.1016/S0264-8377(01)00010-2

Yu, L., \& Zhou, B. (2011). The Compact City Form: Case Study of Shenzhen. Master Thesis. Karlskrona: Blekinge Institute of Technology, 67 p. Retrieved from: http://www.divaportal.org/smash/get/diva2:829367/FULLTEXT01.pdf

\section{AUTHOR'S SHORT BIOGRAPHY}

Vladyslav Smilka graduated from Kyiv National University of Building and Architecture, majoring in Cadastre in 2001. In 2008, he defended his Doctoral Thesis for the degree of Candidate of Technical Sciences in the specialty "Urban Planning and Spatial Planning". He is the author of more than 55 scientific works in the field of town-planning cadastre, town-planning monitoring, and regulation of land relations in human settlements.

Email: vlsmilka@gmail.com

ORCID iD: https://orcid.org/0000-0002-7025-9398 